\title{
Using of Sensitivity Analysis in Road Transport Pricing
}

\author{
Jindřich Ježek ${ }^{1 *}$, Jiř́ Nožička ${ }^{1}$ and Árpád Török ${ }^{3}$
}

${ }^{1}$ University of Pardubice, Faculty of Transport Engineering, Department of Transport Management, Marketing and Logistics, Studentská 95, Pardubice 532 10, Czech Republic; Email:

Jindrich.jezek@upce.cz,jiri.nozicka@upce.cz

${ }^{2}$ Budapest University of Technology and Economics, Department of Transport Technology and Economics, Muegyetem ekp 3., Budapest, H-1111, Hungary,Email: torok.arpad@mail.bme.hu

\section{*Corresponding Author: Jindřich Ježek}

\begin{abstract}
The paper deals with the issue of sensitivity analysis and its possible use in price formation in passenger road transport. The input variables are selected on the model example. Based on the calculation, the sensitivity of the output to these input variables is determined, and the question how these inputs affect the overall result is answered.
\end{abstract}

Keywords: Sensitivity analysis, transportation, costs, pricing

\section{Introduction}

Sensitivity analysis is a calculation method that examines the effect of changing the input variables on their outputs (results).

Sensitivity analyses can be divided by several aspects - by scope, focus and complexity. In terms of scale, partial and total sensitivity analyses can be distinguished. For Partial sensitivity analyses, the influence of only several selected inputs is tested. In the case of complete sensitivity analyses, the influence of all input parameters is tested. Sensitivity analysis can be focused on criteria or decisions. In case of focusing on criteria, the main purpose of the analysis is to determine the influence of the individual parameters and then to determine the order of their importance to the output. Focusing on decisions means trying to find boundary values for inputs where there is a meaningful change in results - for example, when the order of each solution variant changes. In terms of complexity, one-dimensional and multidimensional analyses are distinguished. Onedimensional sensitivity analysis always changes the values of only one input and the other model parameters remain constant. In this way, the influence of the test input variable on the result can be determined unambiguously without distortion. The drawback is the fact that in real-time applications, only one input changes occur very rarely and therefore, the tested scenario is purely theoretical. This deficiency can be removed by Multidimensional sensitivity analyses that 
simultaneously change the values of multiple input variables and evaluate their combined effect on the output of the calculation. The disadvantage of this type of testing can be its difficulty and complexity.

In general, Sensitivity analysis can be performed for each calculation model regardless of its application. By default, the sensitivity to the input values is determined especially in investment decision making as part of this contribution the authors focused on the possibility of application in the context of pricing in passenger road transport.

Sensitivity analysis was used by Du, Nicholson (1997) for Analysis of Degradable transportation systems or by Jourquin, Beuthe (1996) for analysis on the relative road costs. Olso Tzeng, Lin, Opricovic (2005) used sensitivity analysis in Multicriteria analysis of alternative-fuel buses for public transportation [1-3].

\section{Data and Methods}

Sensitivity analysis, which is sometimes also called as What-if analysis, serves as a tool for a crosscalculation of the selected variables. Thanks to this analysis, it is possible to calculate the sensitivity of the selected indicator to individual changing components.

Sensitivity analysis responds to the question which factor will mostly affect the company's profit. In pricing it is important to focus on profit-creating components. In addition, if the company can use sensitivity analysis it can significantly increase its readiness and ability to cope with changing factors. Due to the sensitivity analysis, if one of the factors which influence the profit changes (either upwards or downwards) the company can assume its impact on the final price and respond to this change quickly and effectively.

In the following example, a sensitivity analysis calculation is performed. It can be used as a tool for determining the price for services in road transport mode. Sensitivity analysis was used according to Schmitt-Grohé and Uribe, (2003) [4,5].

The company's profit is determined by the difference in costs and revenues. In this case, the profit is zero (i.e. at the break-even point) it consists of the four following components: - Volume of transport q per year (in this case mileage),

- variable cost per $1 \mathrm{~km}$,

- fixed costs for the base period (a year);

- cost per $\mathrm{km}$.

The key question in using sensitivity analysis is changing of factor (the components of profit) mostly affects the company's profit. Using the calculations of the individual sensitivity components, it examines their possible changes and their sensitivity to change. For example, if it examines the 
price it answers the question of what is the minimum possible price for which the company is willing to sell its product and which is not loss-making (i.e. it will generate profit or cover costs).

\section{Division of Costs for Calculating the Sensitivity Analysis}

Sensitivity analysis calculations include estimating of costs which affect profits. For this reason, it is important to divide the costs into variable costs and fixed costs. The variable costs are calculated per unit, in this case per one kilometre. On the other hand, fixed costs must relate to the base period of one year. Total costs are calculated according to the formula given in formula (1):

$$
N=v \times q+F,[\mathrm{CZK}]
$$

Where:

$N$ are total costs $[\mathrm{CZK}] ; v$ are variable unit costs per $1 \mathrm{~km}[\mathrm{CZK} / \mathrm{km}] ; q$ is the number of kilometres travelled $[\mathrm{km}] ; F$ are fixed costs $[\mathrm{CZK}]$ per basic period (year).

The calculated cost per kilometre is presented below in Tables 1, 2 and 3, which show in detail variable and fixed costs. The data entered in the Tables together with the expected capacity are the real values for the company $\mathrm{ABC}$ in the year 2016. Because of the required anonymity, the name of the company is fictitious $[5,6]$.

Table 1 Calculation of variable cost per kilometre. Source: ABC's internal materials

\begin{tabular}{|l|r|r|}
\hline Variable costs of using a car in $\mathbf{2 0 1 6}$ & \multicolumn{2}{|c|}{$\mathrm{km}$} \\
\hline Annual mileage & 5,000 & $1 / 100 \mathrm{~km}$ \\
\hline Fuel consumption & 33 & $\mathrm{CZK} / \mathrm{l}$ \\
\hline Average price of fuel & 8,250 & $\mathrm{CZK}$ \\
\hline Price of fuel per year & 4,800 & $\mathrm{CZK}$ \\
\hline Price of a summer tire set & 4,800 & $\mathrm{CZK}$ \\
\hline Price of a winter tire set & 50,000 & $\mathrm{~km}$ \\
\hline Mileage to replace the tire set & 17 & yrs \\
\hline Years to replace summer tires & 24 & yrs \\
\hline Years to replace winter tires & 282 & $\mathrm{CZK}$ \\
\hline Summer tires costs per year & 200 & $\mathrm{CZK}$ \\
\hline Winter tires costs per year & 1,000 & $\mathrm{CZK}$ \\
\hline 2 Switches of tires per year & 5,000 & $\mathrm{CZK}$ \\
\hline Average Repairs and maintenance per year & $\mathbf{1 4 , 7 3 2}$ & $\mathbf{C Z K}$ \\
\hline Costs of the year & $\mathbf{2 . 9 5}$ & CZK \\
\hline Variable costs of a car per $\mathbf{k m}$ & & \\
\hline
\end{tabular}


Table 2 Calculation of annual fixed costs per one vehicle. Source: ABC's internal materials

\begin{tabular}{|l|r|r|}
\hline Fixed costs per car \\
\hline Highway tolls & 1,500 & CZK \\
\hline Annual insurance & 5,000 & CZK \\
\hline Annual compulsory liability & 2,000 & CZK \\
\hline Purchasing price of car & 250,000 & CZK \\
\hline Number of years of use & 10 & yrs \\
\hline Price of car on sale & 82,500 & CZK \\
\hline Annual loss for the purchase of a car & 16,750 & CZK \\
\hline Annual Fixed costs per car & $\mathbf{2 5 , 2 5 0}$ & CZK \\
\hline Fixed costs of a car per 1 km & $\mathbf{5 . 0 5}$ & CZK \\
\hline
\end{tabular}

Table 3 Calculation of total costs per kilometre Source: authors

\begin{tabular}{|l|l|l|}
\hline Variable costs of a car per $\mathrm{km}$ & 2.95 & CZK \\
\hline Fixed costs of a car per $1 \mathrm{~km}$ & 5.05 & CZK \\
\hline TOTAL COSTS of a car per $1 \mathrm{~km}$ & $\mathbf{8 . 0 0}$ & CZK \\
\hline
\end{tabular}

\section{Application of Sensitivity Analysis on Model Example}

To demonstrate how to determine the sensitivity analysis, a calculation will be made in the following example. The calculation is made for one model vehicle. The basis for the calculation is as follows [6-8]:

- expected (estimated) capacity (qK) ... 8,000 km/year,

- service price $(\mathrm{C}) \ldots 8.00 \mathrm{CZK} / \mathrm{km}$,

- variable cost / kilometre (v) ... $2.95 \mathrm{CZK}$,

- fixed costs / year (F) ... 25,250 CZK.

The sensitivity analysis calculation has the following steps:

(a) determining the break-even point,

(b) the safety factor for the expected use of the vehicle,

(c) profit on the expected use of the vehicle,

(d) sensitivity of demand, price, variable costs and fixed costs in the expected use of the vehicle.

Procedure:

(a) The first step is to determine the break-even point (BZ) which indicates the minimum mileage required for the equality of revenues and costs. The number of kilometres at the break-even point is $\mathrm{q}_{\mathrm{BZ}}$, the calculation procedure according to formula (2).

$$
v \times q_{B Z}+F=C \times q_{B Z},
$$

$\boldsymbol{q}_{\boldsymbol{B} Z}$ needs to be expressed from this formula: 


$$
q_{B Z}=\frac{F}{C-v}=\frac{25250}{8-2,95}=5000 \mathrm{~km}
$$

The break-even point corresponds to $5,000 \mathrm{~km}$. In case of this volume, the company does not generate any profit but revenues cover all costs.

b) The safety coefficient (BK) related to the expected use of the vehicle indicates how large the reserve of expected mileage compared to the required mileage is. Otherwise, how much \% may the mileage drop without the occurrence of loss $[6,9]$.

$$
B K=\frac{q_{K}-q_{B Z}}{q_{K}} \times 100=\frac{8000-5000}{8000} \times 100=37,5 \%
$$

The expected mileage $(8,000 \mathrm{~km})$ may fall by up to $37.5 \%$, i.e. to $5,000 \mathrm{~km}$, and this drop will still not create loss.

c) Profit at expected mileage

$$
Z_{q k}=V-N=C \times q_{K}-q \times q_{K}-F=8 \times 8000-2,95 \times 8000-25250=15150,-C Z K
$$

If the service expectation is fulfilled and there will be an annual mileage of $8,000 \mathrm{~km}$ for one vehicle this vehicle will earn $15,150 \mathrm{CZK}$ on profit per year.

d) The sensitivity of individual components indicates the percentage change in the range in which their values can move without the company's activity being unprofitable. The individual components are expressed based on the following relation (3) [10]:

$$
c \times q_{c}-v \times q_{c}=F
$$

Sensitivity of demand, i.e. quantity $\mathrm{q}_{\mathrm{c}}$, is examined for the expected amount of kilometres

Expression of the minimum $\mathrm{q}_{\mathrm{c}}$ :

$$
q_{c}=\frac{F}{C-v}=\frac{25250}{8-2,95}=5000 \mathrm{~km}
$$

Sensitivity $\left(\mathrm{S}_{\mathrm{qc}}\right)$ :

$$
S_{q c}=\frac{q_{K}-q_{C}}{q_{K}} \times 100=\frac{8000-5000}{8000}=37,5 \%
$$

Sensitivity of Demand indicates that the expected plan of $8.000 \mathrm{~km}$ can drop by a maximum of $37.5 \%$ to $5.000 \mathrm{~km}$. If the annual mileage was below this value it would lead to loss.

Sensitivity of price $\left(S_{c}\right)$ per unit (kilometre) is calculated from the formula:

$$
S_{C}=\frac{C-C_{C}}{C} \times 100=\frac{8-6,11}{8} \times 100=23,63 \%
$$


This calculation represents the possibility of decreasing the set price of $8 \mathrm{CZK}$ up to $23.63 \%$, to the price $6,11 \mathrm{CZK}$.

$$
C_{C}=\frac{F+v \times q_{K}}{q_{K}}=\frac{25250+2,95 \times 80000}{8000}=6,11 \mathrm{CZK}
$$

$\mathrm{C}_{\mathrm{C}}$ is minimal price that will generate zero profit from mileage 8.000 kilometres.

Sensitivity of the variable costs $\left(S_{v}\right)$, i.e. costs which are changing the value along with changing of mileage. This sensitivity is calculated as follows:

$$
v_{c}=\frac{C \times q_{K}-F}{q_{K}}=\frac{8 \times 8000-25250}{8000}=4,84 C Z K
$$

According to the calculation of Sensitivity of the variable costs, they can be increased to a unit price of $4,84 \mathrm{CZK} / \mathrm{km}$ without affecting the demand or the cost of the service.

$$
S_{v}=\frac{v-v_{C}}{v} \times 100=\frac{2,95-4,84}{2,95} \times 100=-64,2 \%
$$

The variable costs per unit may be increased by up to $64.2 \%$ compared to the original variable costs.

Sensitivity of the fixed costs $\left(\mathrm{S}_{\mathrm{F}}\right)$, i.e. costs which are fixed for the base period (year). Fixed costs do not change with varying mileage.

$$
\begin{aligned}
& F_{C}=(C-v) \times q_{K}=(8-2,95) \times 8000=40400 \mathrm{CZK} \\
& S_{F}=\frac{F-F_{C}}{F} \times 100=\frac{25250-40400}{25250} \times 100=-60 \%
\end{aligned}
$$

Annual Fixed costs may increase by $60 \%$ without affecting the occurrence of loss. In case of such an increase, the profit will be zero. Revenues will cover the costs.

\section{Final Order of Sensitivities}

Once these partial calculations have been made, the results can be sorted according to sensitivity reaction to the change. This order is displayed in the following Table 4.

Table 4 Final order of sensitivities. Source: authors

\begin{tabular}{|r|l|c|r|r|}
\hline Order & Sensitivities & Change (v \%) & Basic value & \multicolumn{1}{|c|}{ Break-even point } \\
\hline 1. & Price & $\downarrow 23.63$ & $8.00-\mathrm{CZK}$ & $6.11 \mathrm{CZK}$ \\
\hline 2. & Demand & $\downarrow 37.5$ & $8,000 \mathrm{~km}$ & $5.000 \mathrm{~km}$ \\
\hline 3. & Fixed costs & $\uparrow 60$ & $25,250,-\mathrm{CZK} / \mathrm{yrs}$ & $40,400,-\mathrm{CZK} / \mathrm{yrs}$ \\
\hline 4. & Variable costs & $\uparrow 64.2$ & $2.95 \mathrm{CZK} / \mathrm{km}$ & $4.84 \mathrm{CZK} / \mathrm{km}$ \\
\hline
\end{tabular}




\section{Evaluation of the Proposed Use of Sensitivity Analysis}

Sensitivity analysis enables a company to determine which components affect its profits. Based on previous calculations, it is possible to use sensitivity analysis to determine pricing as the company can have a reliable overview of important areas. Looking at Table 4 with the order of sensitivity, it can be stated that the most sensitive to change is price so it is important for the company to be alert to the changes that may affect the price significantly. Just a small change of another factor can be a complication in the acceptability of the market price. For example, if fixed costs rise due to the purchase of a more expensive car the price is not so flexible that it can respond smoothly [11-13].

\section{Conclusion}

Using sensitivity analysis enables us to focus on the components that affect profits. Once it is defined and quantified it is clear what component is sensitive to change and able to respond to it. Through this analysis, the company will have a clear idea of the component it should focus on and try to avoid its excessive fluctuations.

By applying this method to a real pricing process, companies in the field of competition can greatly influence their competitive position and become more flexible to price changes. At the same time, however, it is necessary to take into account the preservation of the attractiveness of the service offered and to ensure the effective linking of new procedures with a focus on the quality provided.

\section{References}

[1] Du, Z.P. \& Nicholson, A. (1997). Degradable transportation systems: Sensitivity and reliability analysis. Transportation Research, 31(3), 225-237.

[2] Jourquin, B. \& Beuthe, M. (1996). Transportation policy analysis with a geographic information system: The virtual network of freight transportation in Europe. Transportation research, 4(6), 359-371.

[3] Tzeng, G.H., Lin, Ch.W. \& Opricovic, S. (2005). Multi-criteria analysis of alternative-fuel buses for public transportation. Energy Policy, 33(1), 1373-1383.

[4] Samson, A. (2017). An introduction to Behavioral Economics. Retrieved April 05, 2017, Available at: https://www.behavioraleconomics.com/introduction-behavioral-economics.

[5] Schmitt-Grohé, S. \& Uribe, M. (2003). Closing small open economy models. Journal of International Economics, 61(1), 163-185. 
[6] Ekonomikon. (2016). Postup stanovení ceny. Retrieved January 09, 2017, Available at: http://www.ekonomikon.cz/ekonomika/cena/stanoveni.

[7] IPodnikatel. (2013, Febuary). Cenové strategie. Retrieved January 18, 2017, Available at: http://www.ipodnikatel.cz/Strategie-podnikani/cenove-strategie-jak-stanovit-cenuproduktu.html.

[8] Kampf, R., Stopka, O., Kubasakova, I. \& Zitricky, V. (2016). Macroeconomic Evaluation of Projects Regarding the Traffic Constructions and Equipment. Procedia Engineering 161, In World Multidisciplinary Civil Engineering-Architecture-Urban Planning Symposium, (WMCAUS 2016), 13-17 June 2016 (pp. 1538-1544). Prague, Czech Republic; Code 132600. DOI: 10.1016/j.proeng.2016.08.623.

[9] Kampf, R., Lorincová, S., Hitka, M. \& Caha, Z. (2016). The application of ABC analysis to inventories in the automatic industry utilizing the cost saving effect. Nase More, 63(3), 120125. DOI: $10.17818 / \mathrm{NM} / 2016 / \mathrm{SI} 8$.

[10] Gumz, F. \& Török, Á. (2015). Investigation of cordon pricing in Budakeszi. Periodica Polytechnica. Transportation Engineering, 43(2), 92-97. DOI: 10.3311/PPtr.7579.

[11] Abramovic, B. (2017). Passenger's Satisfaction on Long Distance Terminals: Case Study City of Zagreb. Periodica Polytechnica. Transportation Engineering, 45(1), 42-47. DOI: 10.3311/PPtr.9197.

[12] Chovancova, M. \& Klapita, V. (2017). Modeling the Supply Process Using the Application of Selected Methods of Operational Analysis. Open Engineering, 7(1), 50-54. DOI: 10.1515/eng2017-0009.

[13] Glavic, D., Milos, M., Luttinen, T., Cicevic, S. \& Trifunovic, A. (2017). Road to price: User perspectives on road pricing in transition country. Transportation Research Part A-Policy and Practice, 105, 79-94. DOI: 10.1016/j.tra.2017.08.016. 